\title{
Zeynep Sezen Tan Özyaşam (1946-2021)
}

\section{Zeynep Sezen Tan Autobiography (1946-2021)}

\section{Sinan-Barış Tan*}

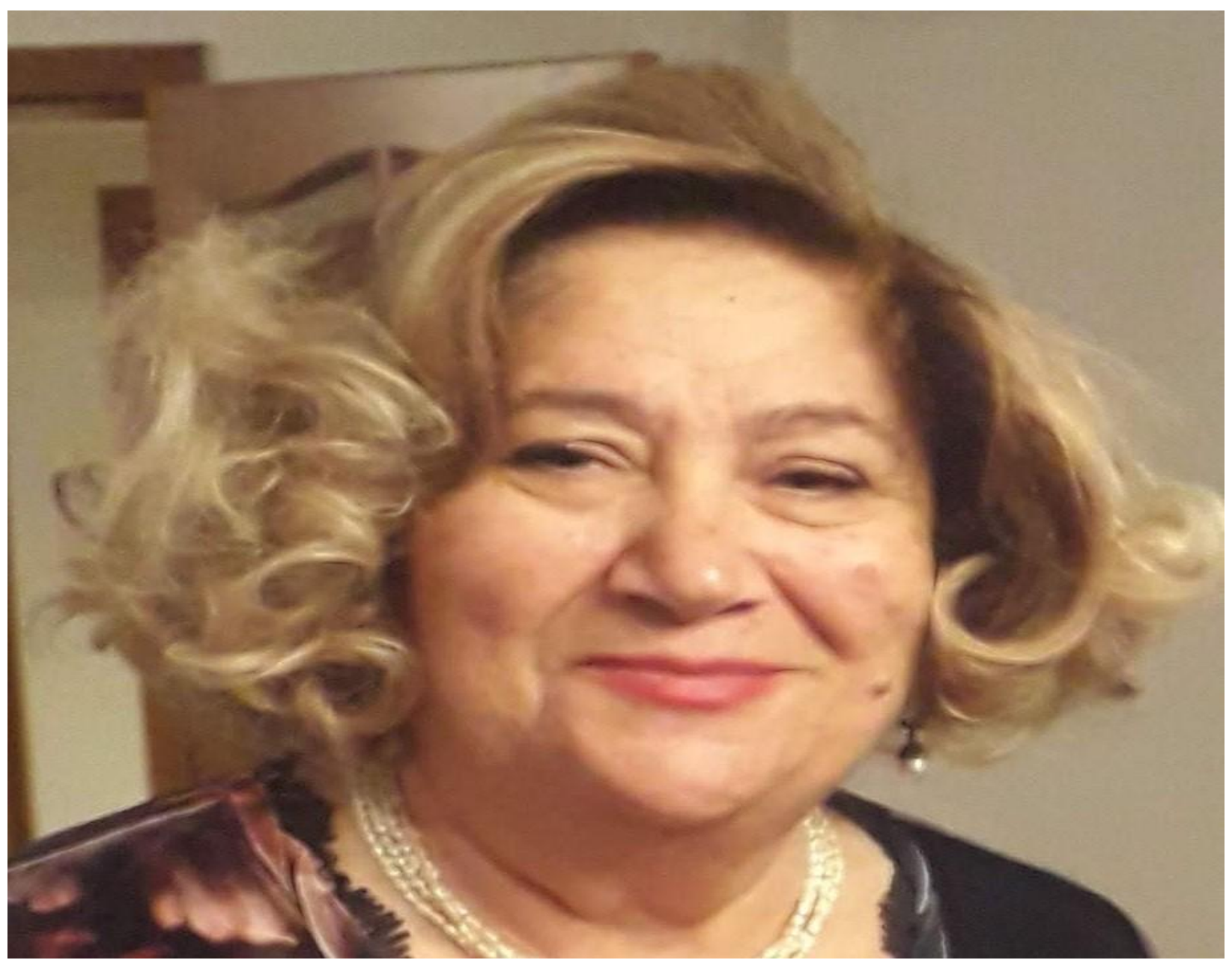

Zeynep Sezen Tan 1946 yılında Ankara'da doğmuştur. Öğretmen Emine Doğancı ve Çanakkale ve İstiklal Savaşı Gazisi Abdullah Doğancı'nın biricik kızları ve ikinci çocuklarıdır. Ortaokul ve Liseyi TED Ankara Koleji'nde okumuş, 1964'de mezun olmuştur. Dil ve TarihCoğrafya Fakültesi Kütüphanecilik Bölümü'nü 1968'de bitirmiştir. Aynı yıl Hacettepe

\footnotetext{
* E-posta: sinan@iletisimteknolojisi.com

E-mail:sinan@iletisimteknolojisi.com
}

Geliş Tarihi-Received: 13.12.2021

Kabul Tarihi - Accepted: 15.12.2021

Yayımlanma Tarihi - Published: 30.12.2021 
Üniversitesi Kütüphanesinde ise başlamıştır. Çalışırken, Üniversite'nin Kütüphanecilik Bölümü'nde master yapmıştır. 1979 da bitirdiği Tezinin başlığ " "Hacettepe Üniversitesi Kütüphane Hizmetlerinin Planlanmasına İlişkin Görüşler”'dir. Hacettepe Üniversitesi Kütüphanesinde bölüm çalışanı, bölüm şefi, kütüphane müdüresi ve nihayetinde Kütüphane ve Dokümantasyon Daire Başkanı olarak 23 seneyi aşan hizmetinden 1991'de emekli olmuştur. Emekliliğinin hemen ardından araştırma kütüphanelerine uluslararası akademik yayıncıların veritabanlarının sunulmasında önderlik etmiş ve bu konuda uzmanlaşmış bir firma kurmuştur. 2018'de bu firmaya 27 y1l emek verdikten sonra 50 yıllık meslek yaşantısını ikinci emekliliği ile sonlandırmıştır. Özel sektördeki çalışma hayatı sırasında uluslararası standartlarda bir ulusal toplu kataloğumuzun oluşması için yoğun çaba göstermiş, bu konuda ulusal çalıştaylar düzenlemiştir. Zeynep Sezen Tan, Üniversite ve Araştırma Kütüphanecileri Derneği'nin (ÜNAK) kurucu üyelerindendir. Ayrıca Türk Kadınlar Konseyi Derneği Ankara Şubesi kurucu başkanıdır. İki çocuk annesi Zeynep Sezen Tan 2021 yılının Ağustos ayında vefat etmiştir. Anısı önünde saygıyla eğiliriz.

Zeynep Sezen Tan was born in Ankara in 1946. She is the only daughter and the second child of Emine Doganci who was a teacher and Abdullah Doganci who was a Dardanelles and Independence War veteran. She attended Middle School and High School at TED Ankara College and graduated in 1964. She graduated from the Library Science Department of Ankara University, Faculty of Languages and History-Geography in 1968. That same year, she started work at the Hacettepe University library. While working she obtained a masters degree from the Library Science Department of the University. The title of her masters thesis, which she completed in 1979, was "Hacettepe Üniversitesi Kütüphane Hizmetlerinin Planlanmasina İlişkin Görüşler". She started out as department staff, and then became department chief, library director and eventually the Head of Library and Documentation and retired in 1991 after 23 years of service at the library. Right after her retirement, she pioneered in bringing international academic publishers' databases to research libraries and established a firm focused on this area. After 27 years of work at this firm, she concluded her 50 years of library career by getting retired a second time. During her work life in the private sector, she gave immense effort to create a national union catalog that met international standards and organized national workshops on this matter. Zeynep Sezen Tan is a founding member of Üniversite ve Araştırma Kütüphanecileri Derneği (University and Research Librarians Association, ÜNAK). In addition, she is the Founding President of Türk Kadinlar Konseyi Derneği, Ankara Branch (National Council of Turkish Women). Zeynep Sezen Tan is a mother of two children and passed away in August, 2021. We bow respectfully before her memory. 